\title{
EARLY STRENGTHENING OF DOMINANT ENTREPRENEURIAL CHARACTERS TO REACH THE SECOND CAREER OPPORTUNITY OF BEING ENTREPRENEURS
}

\section{Iffah Budiningsih ${ }^{1+}$ \\ Tjiptogoro Dinarjo Soehari ${ }^{2}$ \\ Akhmad Tarmizi ${ }^{3}$}

\section{Article History}

Received: 12 February 2021 Revised: 16 March 2021

Accepted: 19 April 2021

Published: 24 May 2021

\section{Keywords}

Second career

Entrepreneurial characters

Innovative

Risk-taking

Self-determined.

\author{
'As-Syafi'iyah Islamic University, Jakarta, Indonesia. \\ Email:iffah_budiningsih@uia.ac.id \\ ${ }^{2, s}$ Universitas Mercu Buana, Jakarta, Indonesia.
}

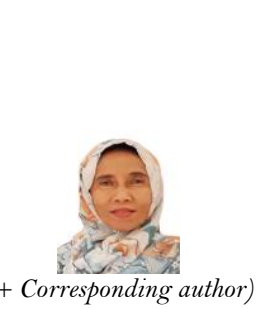

ABSTRACT

The retirement age of Indonesian employees ranges from 58 to 65 years and this gives an opportunity for retired employees to develop the second career of being entrepreneurs. The purpose of this study was to identify dominant entrepreneurial characters among male field officers of one of the forces in The Indonesian National Armed Forces in Jakarta. This study relied on a survey involving 200 samples, which were taken by proportional simple random sampling from 1,120 accessible population. Furthermore, the data were analyzed using descriptive analysis with SPSS 25. The results revealed that 1) $69.50 \%$ of the respondents were predicted to only enjoy retirement and not willing to work again. This would increase the number of under employment; 2) dominant entrepreneurial characters of Indonesian National Army field officers, i.e., being innovative, risk-taking, and self-determined, had not met the standard score for being entrepreneurs, and only considered having a 'moderate' category. The average scores of innovative $=3.16$, risk-taking $=3.15$, and selfdetermined $=3.14$. Meanwhile, being entrepreneurs needed to reach scores in the high/very high category of 4.0 - 5.0;3) a program of dominant entrepreneurial character strengthening was required in all professions as retirement preparation.

Contribution/ Originality: The results of this study are an advisory document to government/nongovernment agencies that retired employees are not an additional source of unemployment, therefore it is necessary to strengthen the entrepreneurial character of their employees to develop a second career in entrepreneurship after retirement age (58-60 years) as the implementation of the concept of "indirect compensation (security, safety, and health).

\section{INTRODUCTION}

Based on the data from Statistics Indonesia, it is predicted that the number of workforces with productive age (15-64 years) arrive at $69.32 \%$ of Indonesia's total population in 2020. The remaining $30.68 \%$ are those with unproductive age (0-14 years and above 64 years) (see Table 1). Abundant productive-aged human resources in Indonesia can be utilized to improve their productivity to meet the era of industry 4.0 that is full of competition. The retirement age of Indonesian National Army officers ranges from 58 - 60 years, in which most of them are physically healthy. This is due to the improving health quality characterized by the increased in life expectancy up to approximately 70 years old. The birthrate is currently declining, making the number of productive populations (aged 15-64 years) higher than the unproductive ones (aged 0-14 years and above 64 years); this occurs in almost all 
countries across the world, including Indonesia. This situation has become an opportunity to spur economic growth due to the plentiful productive-aged workforces (69.32\%) at hand. Some of them are retired (aged 58 - 65 years) from state civil apparatus, of Indonesian National Army, state/regional-owned enterprises, and private sectors (government and non-government employees). The focus of this study is on the process of optimizing the retired/before-being-retired human resources to be productive or the process of reaching the opportunity of the second career after retirement. Entrepreneurial character strengthening will be an entry point to develop or find job opportunities as the second career after retirement. The data from Statistics Indonesia, as presented in Table 1, show that the number of workforces aged 55 - 60 years who were still productive were quite high, i.e., $98.35 \%$ of 55 - 69 years old, and $98.25 \%$ of $>60$ years old.

Table-1. Data from Statistics Indonesia: Workforces based on Age per February 2019

\begin{tabular}{|c|c|c|c|c|c|c|}
\hline \multirow[b]{3}{*}{ Age } & \multicolumn{6}{|c|}{ Per February 2019} \\
\hline & \multicolumn{4}{|c|}{ Workforces (WF) } & \multirow[b]{2}{*}{$\begin{array}{c}\text { Total Population } \\
\text { Aged } 15 \text { Years } \\
\text { and Above }\end{array}$} & \multirow[b]{2}{*}{$\begin{array}{c}\text { Percentage of WF } \\
\text { towards Working } \\
\text { Age Population }\end{array}$} \\
\hline & Employed & Unemployed & $\begin{array}{c}\text { Number of } \\
\text { WF }\end{array}$ & $\begin{array}{c}\% \\
\text { Working } / \\
\text { WF }\end{array}$ & & \\
\hline $15-19$ & $5,053,409$ & $1,046,977$ & $6,100,386$ & 82.84 & $22,278,283$ & 27.38 \\
\hline $20-24$ & $13,168,707$ & $2,266,192$ & $15,434,899$ & 85.32 & $21,886,591$ & 70.52 \\
\hline $25-29$ & $15,047,468$ & $1,240,411$ & $16,287,879$ & 92.38 & $21,194,314$ & 76.85 \\
\hline $30-34$ & $15,547,139$ & 583,911 & $16,131,050$ & 96.38 & $20,564,825$ & 78.44 \\
\hline $35-39$ & $15,966,136$ & 424,892 & $16,391,028$ & 97.41 & $20,237,032$ & 81.00 \\
\hline $40-44$ & $15,548,990$ & 332,709 & $15,881,699$ & 97.91 & $19,292,589$ & 82.32 \\
\hline $45-49$ & $14,294,711$ & 321,508 & $14,616,219$ & 97.80 & $17,588,067$ & 83.10 \\
\hline $50-54$ & $12,186,866$ & 207,542 & $12,394,408$ & 98.33 & $15,299,367$ & 81.01 \\
\hline $55-59$ & $9,396,050$ & 157,823 & $9,553,873$ & 98.35 & $12,607,997$ & 75.78 \\
\hline $60+$ & $13,156,716$ & 234,875 & $13,391,591$ & 98.25 & $25,513,700$ & 52.49 \\
\hline Sum Total & $129,366,192$ & $6.816,840$ & $136,183,032$ & 94.99 & $196,462,765$ & 69.32 \\
\hline
\end{tabular}

Every human is created to have different and unique characters from one another. These characters were either from birth or shaped during childhood or the interaction with the environment. Lickona (2016) mentions three interconnected parts of characters, including 1) knowledge of good things; 2) feeling/desire of good things; 4) doing good things. Moreover, Budiningsih., Masduki, and Heri (2018) argue that characters are generally stated as a set of traits that influence one's thought, feeling, and behavior that the formation is from genetic factors, habits, environmental effects, or life experiences. People's characters can be seen from their behavior, and frequently used as a synonym of personalities. However, Gordon Allport in Hjelle and Daniel (1992) opines that characters are different from personalities, in which personalities are actions one does to express himself/herself. Characters, on the other hand, are connoted as moral standards or value systems that judge a person's actions. For this reason, characters are part of personalities. It is assumed that several dominant characters of entrepreneurship as a mainstay to be an entrepreneur are being innovative, risk-taking, and self-determined.

Innovative character is quite dominant in entrepreneurship. According to Ireland, Hoskisson, and Hitt (2011) innovative character depicts the behavior of the process of creating products (goods and services) with commercial values by producing or developing new products/processes. This notion indicates that innovative behavior serves as the function of entrepreneurship. In addition, Carmeli, Meitar, and Weisberg as cited by Barrand, Sanseau, and Ferrante (2012) explain that the complexity of one's innovative behavior encompasses three stages of processes, which are a) at first, a person will recognize problems and find solutions and new ideas or adoption results; b) a person will find ways to propose solutions and ideas, develop legitimizations, and look for supports from inside or outside the organization; c) a person will build up prototypes or models to be tested. Syifa, Budiningsih, Djaelani, and Ahmad (2017) describe that innovative behavior refers to individuals' actions that are directed to produce, 
introduce, or apply new advantageous ideas or solutions in every level of activities. These activities are indicated by efforts to raise ideas, find opportunities, gaining supports, striving for ideas, and implementing the ideas.

Humans must make a routine, easy, temporary, or difficult decisions, starting from those with no risk, low risk, and high risk; this is based on their option. Some of them prefer making a safe and convenient decision with no risk at all. Nonetheless, some also would rather choose a decision with a quite high risk, yet providing an expectation of maximum achievement, although with high uncertainty. Sallahand Ibrahim in Chipeta and Surujlal (2017) define 'risk-taking' as a character one has regarding his/her ability to assume the level of uncertainty in every business activity. Besides, Hatta (2014) claims that willing to take risks is an active ability to chase opportunities, although these opportunities are risky and have uncertain outcomes.

Another dominant character of entrepreneurship is self-determined, or in other words, being passionate to compete with others in terms of getting achievements. Such a character serves as an essential factor to reach entrepreneurial success. Competitive passion for having achievements is a responsive attitude towards every challenge an entrepreneur face. Many entrepreneurs often consider challenges a threat that can prevent them from reaching their success. Thus, they need to counter the challenges to win the competition or to succeed. One of the bases of self-determined character is the motivation to get achievements. Mulyana (2013) points out that motivation to get achievements refers to one's encouragement related to achievement with the following characteristics: dominating, manipulating, and managing the physical or social environment, overcoming obstacles, maintaining good work quality, competing through efforts to exceed past actions, and surpassing others' actions. On that ground, 'self-determined' is an attitude to compete to gain achievements that is shown by a responsive attitude to anticipate each business activity of the competitors. Further, Purwanto (2014) opines that someone will have a motivation to be self-determined if s/he has 1) the ability to finish task accurately and quickly, as well as believing that any actions are valuable to him/her; 2) high efficacy, i.e., high confidence for having broad knowledge and experience; 3) clear and measurable goal orientation.

The characters of being innovative, risk-taking, and self-determined are assumed to dominantly contribute to one's entrepreneurial skills. These characters should be continuously developed and strengthened, so that s/he can survive in reaching opportunities to succeed, both in undergoing the main career as an entrepreneur and the second career after retirement. In responding to the notion, this study involves field officers of Indonesian National Army who are commonly known to be physically healthy. Hence, when they age 58 years (retirement age), they will remain healthy and need a second career. The purpose of this study is to identify dominant characters as the key to success in entrepreneurship (innovative, risk-taking, self-determined), particularly for the retirees to develop the second career.

\section{METHOD OF STUDY}

This study aimed to analyze/identify the dominant characters descriptively as the key to success in entrepreneurship (innovative, risk-taking, self-determined) among government employees. The variables consisted of 'innovative', 'risk-taking', and 'self-determined'. The details regarding research variables and variables indicators are presented in the following Table 2. Employing a quantitative method with survey technique, this study involved 1,120 of Indonesian National Army male field officers with Major and Lieutenant Colonel ranks in of Indonesian National Army Headquarters Cilangkap, Jakarta, as the accessible population. As many as 200 officers were selected as the sample using the proportional simple random sampling for each work unit. Respondents' characteristics are provided in Table 3. The data were collected using non-test instruments (questionnaires) and Likert scale related to the category of score $5=$ very high, score $4=$ high, score $3=$ moderate, score 2 low, score $1=$ very low. Descriptive analysis using mean and percentage with the assistance of Microsoft Excel and SPSS 25 was applied. 
Table-2. Research variables and indicators.

\begin{tabular}{c|l|l}
\hline No. & Variables & Indicators \\
\hline \multirow{2}{*}{1} & Innovative & a. Self-actualization \\
\cline { 3 - 3 } & & b. Flexibility \\
\cline { 3 - 3 } & & c. Originality \\
\cline { 3 - 3 } & & d. Elaboration \\
\cline { 3 - 3 } & & e. Conceptual skills \\
\hline \multirow{2}{*}{2} & \multirow{2}{*}{ Risk-Taking } & a. Consideration in different options \\
\cline { 3 - 3 } & & $\begin{array}{l}\text { b. Identification of consequences possibility from choosing the } \\
\text { option }\end{array}$ \\
\cline { 3 - 3 } & & c. Being creative and independent \\
\cline { 3 - 3 } & & d. Preferring challenging works \\
\cline { 3 - 3 } & & e. Experiments/experiences \\
\hline \multirow{2}{*}{3} & Self-determined & a. Personal excellence to compete \\
\hline & & b. Differentiation \\
\cline { 3 - 3 } & & c. Focus \\
\cline { 3 - 3 } & & d. Being proactive and responsive \\
\hline
\end{tabular}

Table-3 Characteristics of research respondents.

\begin{tabular}{l|l|c|c}
\hline No & Respondents' Characteristics & Number of Respondents & Percentage \\
\hline \multirow{4}{*}{1} & Age: & 22 & \\
\cline { 2 - 4 } & $<40$ Years Old & 114 & $11.0 \%$ \\
\cline { 2 - 4 } & $40-45$ Years Old & 64 & $57.0 \%$ \\
\cline { 2 - 4 } & $\geq 46$ Years Old & & $32.0 \%$ \\
\hline \multirow{4}{*}{2} & Rank: & 80 & $40.0 \%$ \\
\cline { 2 - 4 } & $-\quad$ Major & 120 & $60.0 \%$ \\
\cline { 2 - 4 } & $-\quad$ Lieutenant Colonel & & $18.0 \%$ \\
\hline \multirow{3}{*}{3} & Years of Service & 36 & $53.5 \%$ \\
\cline { 2 - 4 } & $11-15$ Years & 107 & $28.5 \%$ \\
\cline { 2 - 4 } & $16-20$ Years & 57 & \\
\cline { 2 - 4 } & $\geq 21$ Years & & \\
\hline
\end{tabular}

A validity and reliability test carried out prior to using the research instruments. The validity test applied the formula of the Product Moment coefficient (r), in which the instruments would be valid if the value of $r$ count was 20.30. Meanwhile, the reliability test used the formula of Alpha Cronbach coefficient ( $\mathrm{r}$ ) that the instruments would be reliable if the value of $r$ count got $\geq 0.6$ ). The results are shown in the following Table 4 .

Table-4. The Results of instrument validity and reliability tests.

\begin{tabular}{c|c|c|c|c|c}
\hline No & Variables & $\begin{array}{c}\text { Number of } \\
\text { Instruments }\end{array}$ & $\begin{array}{c}\text { Product Moment } \\
\text { r-count }\end{array}$ & $\begin{array}{c}\text { Reliability } \\
\text { r-coefficient }\end{array}$ & Description \\
\hline 1 & Innovative & 11 & $0.42-0.78$ & 0.90 & Valid \& Reliable \\
\hline 2 & Risk-taking & 10 & $0.30-0.74$ & 0.89 & Valid \& Reliable \\
\hline 3 & Self-determined & 9 & $0.70-0.86$ & 0.91 & Valid \& Reliable \\
\hline
\end{tabular}

\section{RESULTS AND DISCUSSION}

\subsection{Results}

Before the data were descriptively analyzed, it was essential to do an analysis requirement test, i.e., normality test by utilizing the Kolmonov-Smirnov test. It was revealed that all variables (innovative, risk-taking, and selfdetermined) were normally distributed. Besides, before filling out the research instruments, there was a brief indepth interview about activity plans after retirement. The results are given in Table 5 . 
Table-5. The results of in-depth interview with respondents regarding activity plans after retirement.

\begin{tabular}{|c|c|c|c|c|c|}
\hline \multirow[t]{2}{*}{ No } & \multirow[t]{2}{*}{ Activity Plans After Retirement } & \multicolumn{2}{|c|}{ Rank } & \multirow[b]{2}{*}{$\begin{array}{c}\text { Number of } \\
\text { Respondents }\end{array}$} & \multirow[b]{2}{*}{ Percentage } \\
\hline & & Major & $\begin{array}{c}\text { Lieutenant } \\
\text { Colonel }\end{array}$ & & \\
\hline 1 & Looking for another job/ being entrepreneur & 24 & 37 & 61 & $30.5 \%$ \\
\hline \multirow[t]{2}{*}{2} & Enjoying retirement & 56 & 83 & 139 & $69.5 \%$ \\
\hline & Total & 80 & 120 & 200 & $100 \%$ \\
\hline
\end{tabular}

It is concluded from the above table that $30.5 \%$ of the respondents still want to work after they retire. The remaining $69.5 \%$ find it better to enjoy their retirement phase without doing any jobs. The results of the descriptive analysis using mean or average score of respondents' statements in the variables innovative, risk-taking, and selfdetermined are provided in Table 6, 7, and 8. Respondents get an average score of 3.16 in the Innovative character, and include in the moderate category. Similarly, they also arrive at the moderate category with average scores of 3.15 and 3.14, respectively, in the risk-taking and self-determined characters.

Table-6. Average Scores of Respondents' Opinions regarding Instrument Statements in 'Innovative' Variable.

\begin{tabular}{|c|c|c|c|c|}
\hline No & Variable & Indicators & Instrument Statements & Average Scores \\
\hline \multirow{12}{*}{ A } & \multirow[t]{12}{*}{ Innovative } & \multirow[t]{3}{*}{ Self-actualization } & 1. Having good imaginations and ideas. & 3.15 \\
\hline & & & $\begin{array}{l}\text { 2. Being able to actualize ideas becoming useful } \\
\text { things }\end{array}$ & 3.14 \\
\hline & & & 3. Being highly committed to tasks/works & 3.12 \\
\hline & & \multirow[t]{2}{*}{ Flexibility } & $\begin{array}{l}\text { 4. Being able to leave traditional ways of thinking } \\
\text { for new perspectives }\end{array}$ & 3.21 \\
\hline & & & 5. Being flexible to think/act & 3.20 \\
\hline & & \multirow[t]{2}{*}{ Originality } & $\begin{array}{l}\text { 6. Preferring trying new ways in performing } \\
\text { something }\end{array}$ & 3.17 \\
\hline & & & 7. Believing in own ideas & 3.16 \\
\hline & & \multirow[t]{2}{*}{ Elaboration } & $\begin{array}{l}\text { 8. Being able to fix/discover new ideas as a } \\
\text { continuation of previous ideas }\end{array}$ & 3.12 \\
\hline & & & $\begin{array}{l}\text { 9. Being able to modify information for it becomes } \\
\text { helpful }\end{array}$ & 3.20 \\
\hline & & \multirow[t]{2}{*}{ Conceptual Skills } & 10. Being interested in creative activities & 3.17 \\
\hline & & & 11. Having insightful forward-thinking & 3.13 \\
\hline & & & Average Score & 3.16 \\
\hline
\end{tabular}

Table-7. Average scores of respondents' opinions regarding instrument statements in 'risk-taking' variable.

\begin{tabular}{|c|c|c|c|c|}
\hline No & Variable & Indicators & Instrument Statements & Average Scores \\
\hline \multirow[t]{11}{*}{$\mathrm{B}$} & \multirow[t]{10}{*}{ RISK-TAKING } & \multirow{2}{*}{$\begin{array}{l}\text { Consideration } \\
\text { in different } \\
\text { options }\end{array}$} & $\begin{array}{l}\text { 1. Willing to carry out rough works if } \\
\text { necessary }\end{array}$ & 3.18 \\
\hline & & & 2. Willing to work alone without assistance & 3.17 \\
\hline & & \multirow{2}{*}{$\begin{array}{l}\text { Accepting the } \\
\text { consequences } \\
\text { over an option }\end{array}$} & $\begin{array}{l}\text { 3. Willing to get challenging tasks with } \\
\text { uncertain success }\end{array}$ & 3.16 \\
\hline & & & $\begin{array}{l}\text { 4. Willing to start new businesses with } \\
\text { uncertain outcomes }\end{array}$ & 3.19 \\
\hline & & $\begin{array}{l}\text { Being creative } \\
\text { and } \\
\text { independent }\end{array}$ & $\begin{array}{l}\text { 5. Being able to share private ideas with other } \\
\text { parties }\end{array}$ & 3.17 \\
\hline & & \multirow{3}{*}{$\begin{array}{l}\text { Preferring } \\
\text { challenging } \\
\text { works }\end{array}$} & $\begin{array}{l}\text { 6. Choosing tasks with reasonable and } \\
\text { moderate risks }\end{array}$ & 3.17 \\
\hline & & & $\begin{array}{l}\text { 7. Taking into account the application of new } \\
\text { methods with uncertain success }\end{array}$ & 3.16 \\
\hline & & & $\begin{array}{l}\text { 8. Willing to work and think until maximum } \\
\text { achievement }\end{array}$ & 3.12 \\
\hline & & \multirow{3}{*}{$\begin{array}{l}\text { Preferring } \\
\text { experiments }\end{array}$} & $\begin{array}{l}\text { 9. Willing to receive tasks that may be wrong } \\
\text { in the process }\end{array}$ & 3.19 \\
\hline & & & 10. Being ready to do wrong & 3.06 \\
\hline & & & Average Scores & 3.15 \\
\hline
\end{tabular}


Table-8. Average Scores of Respondents' Opinions regarding Instrument Statements in 'Self-determined' Variable.

\begin{tabular}{|c|c|c|c|c|}
\hline No & Variable & Indicators & Instrument Statements & $\begin{array}{l}\text { Average } \\
\text { Scores }\end{array}$ \\
\hline \multirow[t]{10}{*}{$\mathrm{C}$} & \multirow[t]{10}{*}{$\begin{array}{l}\text { SELF- } \\
\text { DETERMINED }\end{array}$} & \multirow[t]{2}{*}{$\begin{array}{l}\text { Personal excellence } \\
\text { to compete }\end{array}$} & $\begin{array}{l}\text { 1. Attempting to have better achievements } \\
\text { without a financial bonus }\end{array}$ & 3.17 \\
\hline & & & $\begin{array}{l}\text { 2. Appreciating work achievements rather } \\
\text { than financial rewards }\end{array}$ & 3.16 \\
\hline & & Differentiation & $\begin{array}{l}\text { 3. Competing actively with fellow workers } \\
\text { for the merit of the company }\end{array}$ & 3.14 \\
\hline & & \multirow[t]{2}{*}{ Focus } & $\begin{array}{l}\text { 4. Attempting to win work or business } \\
\text { competition }\end{array}$ & 3.14 \\
\hline & & & $\begin{array}{l}\text { 5. Attempting to reach goals with smarter } \\
\text { efforts and works }\end{array}$ & 3.13 \\
\hline & & \multirow{4}{*}{$\begin{array}{l}\text { Being proactive and } \\
\text { responsive }\end{array}$} & 6. Being responsive to threats & 3.15 \\
\hline & & & $\begin{array}{l}\text { 7. Being assertive towards business } \\
\text { competitors and/or fellow workers }\end{array}$ & 3.16 \\
\hline & & & $\begin{array}{l}\text { 8. Being self-determined to follow and } \\
\text { defeat fellow workers' career moves }\end{array}$ & 3.16 \\
\hline & & & $\begin{array}{l}\text { 9. Being self-determined to catch up and } \\
\text { defeat the achievement of business } \\
\text { competitors }\end{array}$ & 3.09 \\
\hline & & & Average Scores & 3.14 \\
\hline
\end{tabular}

\subsection{Discussion}

The results of the in-depth interview with 200 respondents before conducting the study signify that $69.5 \%$ of them do not want to work after retirement, and opt to enjoy this phase (see Table 5). The retirement age of Indonesian National Army field officers up to Lieutenant Colonel rank is currently 58 years old, and their physical condition is relatively healthy. The increase in productive human resources is an opportunity to stimulate economic growth due to the abundant productive workforces (reaching $\pm 69.32 \%$ in 2020). Still, if some retirees from Indonesian National Army, state civil apparatus, state/regional/private-owned enterprises with productive age (5864 years) do not want to work again, although they have healthy condition, it will escalate the number of 'under employment' which ends up burdening their family, society, and the country. This matter becomes our responsibility to jointly empower the retirees (human resources) who are included in the productive age of $58-64$ years.

The results of this present study reveal the average scores of respondents' entrepreneurial characters, including innovative $=3.16$, risk-taking $=3.15$, and self-determined $=3.14$. It averagely measures at 3.0 (moderate category). As a matter of fact, entrepreneurial characters require scores that range from $4.0-5.0$ or in high or very high category. Such scores support the results of the in-depth interview that $69.5 \%$ of the respondents will not be working after retirement as they have not got entrepreneurial characters (innovative, risk-taking, and selfdetermined) above the average scores of 4.0 - 5.0. A study conducted by Wardi, Susanto, and Abdullah (2017) indicates that doing entrepreneurship/improving the performance of micro, small, and medium enterprises need the characters of being innovative and proactive in finding business opportunities (self-determined) and daring to take risks.

According to Pachura (2017) the innovative character required to start a business is related to originality, creativity, and ingenuity, where the score should be above average of other people's scores. Pachura also opines that the development and practice of this character need high integrity and a wide social network. Indonesian National Army officers doubtless have high integrity, yet they still have to develop a wide social network to support product marketing through various activities during their active years of service. Furthermore, Sumarwan in Sohari, Budiningsih, and Sari (2019) argues that deciding to perform innovations is, in principle, an activity of finding and processing information. In this case, individuals are motivated to lessen the uncertainty of advantages 
through the following stages: 1) adequate knowledge of innovation; 2) belief in the necessity of innovation through persuasive approach; 3) decision-making of the use of innovation; 4) the implementation of the use of innovation; 5) a confirmation in the form of public acknowledgment of the innovation. These five stages of decision-making of innovation may be adopted by the commander of the Indonesian National Army institution to empower Indonesian National Army officers as human resources. This is to strengthen the innovative character, i.e., increasing the score of this character from averagely 3.16 to approximately 4.0 - 5.0. Here are some interventions to enhance the character of being highly innovative, including 1) training, study tour, internship; 2) accompanying the process of developing ideas and practices of business innovation (business incubator); 3) monitoring and accompanying the process of revising/improving the ideas of innovation; 4) accompanying the application of innovation; 5) accompanying the process of releasing the use of innovation.

The average score of the 'risk-taking' character of research respondent measures at 3.15 and has not satisfied the standard of being an entrepreneur, i.e., ranging from 4.0 - 5.0. Since long ago, TNI has a slogan "Independent or Dead" or "Defend State Honor or Die", so that the officers get used to working with high risks. Nonetheless, it comes to a problem when the research respondents (Indonesian National Army officers) are faced with 'risk-taking' regarding 'business activities.' According to Hyrsky, Tuunanen, Mackoa \& Tyszka in Chipeta and Surujlal (2017) someone who has the character of 'risk-taking' is indicated by 1) adequate knowledge and skills to predict the expected outcome probability; 2) control over the expected outcome of the business that is uncertain. In fact, the respondents have not had these two points as they are yet to get any experiences on entrepreneurship, leading to low knowledge and skills to control uncertain business outcomes. Consequently, they only score 3 averagely in the character of risk-taking (below the standard score of being an entrepreneur). The implication is that being a high risk-taking person as Indonesian National Army officers is not that tough because they already have it. The character only needs to be strengthened by business experiences, and it can be done since the first time joining Indonesian National Army.

The average score of the 'self-determined' character of research respondents accounts for 3.14 (moderate category) and has not met the standard score of being an entrepreneur, i.e., ranging from 4.0 - 5.0 (above the average score of common people. Outstanding behavior is behavior that arises from a person in doing something (goods or services) to pursue the expectation of results that have a high value or value above the standard. Besides, a psychologist named Rotter in Hjelle and Daniel (1992) states that the emergence of self-determined behavior is often based on past experiences in the compared situation, in which if one always makes achievements in the past, s/he will tend to repeat this kind of doing as ever done. If $\mathrm{s} /$ he encounters a situation that is similar to failure, $\mathrm{s} /$ he will tend to avoid the activity. The character of being self-determined is highly required in this era of global competition to improve economic growth. In addition, people with such a character are able to produce quality and competitive products that will enhance the well-being of family, society, and country.

\section{IMPLICATION}

The results of this study provide implications that in order to prevent government or non-government employees from increasing the number of under employment after retirement, which later burdening the family, society, and country, it is essential to conduct a strengthening program of human resources with entrepreneurial characters to every profession. This intends to prepare them to have strong entrepreneurial characters as an asset to develop the second career of being entrepreneurs after the retirement age (58 years). Several forms of interventions of entrepreneurial character strengthening can be designed by the chief of human resource development, such as a delightful strengthening of human resources with entrepreneurial characters during the breaks of the main job. Let alone the fact that there are jobs initially worked by humans, yet they are now replaced by machines. Therefore, they have more time to develop personal capacities, especially entrepreneurial characters. The development of entrepreneurial characters can be carried out through 1) training, study tour, internship; 2) 
accompanying the process of developing ideas and practices of business innovation (business incubator); 3) monitoring and accompanying the process of revising/improving the ideas of innovation; 4) accompanying the application of innovation; 5) accompanying the process of releasing the use of innovation.

Developing/strengthening entrepreneurial characters of being innovative, risk-taking, and self-determined for human resources in Indonesia is a long-term process. Accordingly, the lesson/preparation should be started earlier at school/college. The Policy of Freedom refers to a lesson plan designed by each classroom teacher, and this becomes the entry point to develop entrepreneurial characters early in accordance with every student's potentials and characteristics. By this policy, it seems that a learning program "one-day development of entrepreneurial characters" can be promoted in the learning process.

\section{CONCLUSION}

The increasing number of Indonesian productive-aged workforces (14-64 years) in 2020 is predicted to arrive at $69.32 \%$. This gives an opportunity to develop the second career of being an entrepreneur after retiring that is expected to help the government boost the economic growth of this country. The dominant entrepreneurial characters of The Indonesian National Armed Forces officers, i.e., being innovative, risk-taking, and selfdetermined, have not fulfilled the standard score to develop the second career of being entrepreneurs (moderate category). The average score of innovative $=3.16$, risk-taking $=3.15$, and self-determined $=3.14$. Meanwhile, being entrepreneurs' needs to get scores in the high/very high category (4.0 - 5.0). On that ground, it is crucial to conduct a program of strengthening dominant entrepreneurial characters, e.g., innovative, risk-taking, and self-determined, for government or non-government employees that can be started since they work on the main career. After retirement, they will already have excellent entrepreneurial characters. The intervention of entrepreneurial characters strengthening can be performed through 1) training, study tour, internship; 2) accompanying the process of developing ideas and practices of business innovation (business incubator); 3) monitoring and accompanying the process of revising/improving the ideas of innovation; 4) accompanying the application of innovation; 5) accompanying the process of releasing the use of innovation. Those stages are inspired by the expression 'sow an act and reap a habit, sow a habit and reap a character, sow a character and reap a success.

Funding: This study received no specific financial support.

Competing Interests: The authors declare that they have no competing interests.

Acknowledgement: All authors contributed equally to the conception and design of the study.

\section{REFERENCES}

Barrand, J., Sanseau, P.-Y., \& Ferrante, G. (2012). The leader-member relationship at the core of innovation development: "Member Perceptions, Positions and Expectations”, [In:] D.G. Assimakopoulos, E.G. Carayannis, R. Dossani, (Eds.) Knowledge Perspectives of New Product Development: A Comparative Approach. New York: Springer.

Budiningsih., I., Masduki, A., \& Heri, S. (2018). Model of strengthening the entrepreneurship character through entrepreneurship commitment. Journal of Business and Economics Review, 3(1-4), 28-34.

Chipeta, E. M., \& Surujlal, J. (2017). Influence attitude, risk taking propensity and proactive personality on social entrepreneurship intentions. Polish Journal of Management Studies, 15(2), 27-36. Available at: https://doi.org/10.17512/pjms.2017.15.2.03.

Hatta, I. H. (2014). Analysis of the influence of innovation, risk taking, autonomy, and proactive reactions to the marketing capabilities of regional culinary SMEs in Jabodetabek. Journal of Marketing Management, 8(2), 90-96.

Hjelle, L. A., \& Daniel, J. Z. (1992). Personality theories. New York: McGraw-Hill Inc.

Ireland, R. D., Hoskisson, R. E., \& Hitt, M. A. (2011). The management of strategy: Concept and cases. Mason, OH: South-Western, Cengage Learning.

Lickona, T. (2016). Educating for character, educating for character shaping. Jakarta: PT Bumi Aksara. 
Mulyana, B. (2013). The relationships between self concept, commitment and achievement motivation with freestyle swimming achievement. Jurnal Cakrawala Pendidikan, 32(3), 488-498.

Pachura, A. (2017). Innovation and change in nerwork reality. Polish Journal of Mangement Studies, 15(2), 173-181. Available at: 10.17512/pjms.2017.12.2.16.

Purwanto, E. (2014). Trisula motivation model: New synthesis of outstanding motivation theory. Jurnal Psikologi, Universitas Negeri Semarang, 41(2), $218-228$.

Sohari, T. D., Budiningsih, I., \& Sari, A. (2019). Strengthening of micro business innovation. Journal of Business E Economics Review, 4(3), 131-138.

Syifa, F., Budiningsih, I., Djaelani, A., \& Ahmad, M. (2017). Dominant factors affecting the behavior of innovative employees. Polish Journal of Management Studies, 16(1), 32-40. Available at: https://doi.org/10.17512/pjms.2017.16.1.03.

Wardi, Y., Susanto, P., \& Abdullah, N. L. (2017). Entrepreneurship orientation to the performance of small and medium enterprises (SMEs) West Sumatra: Analysis of the role of moderation of competition intensity, market and technology turbulence. Journal of Technology Management, 16(1), 46-61. Available at: http://dx.doi.org/10.12695/jmt.2017.16.1.4. 